This is the final peer-reviewed accepted manuscript of:

Green Solvent Mixtures for Solid-Phase Peptide Synthesis: A Dimethylformamide-Free Highly Efficient Synthesis of Pharmaceutical-Grade Peptides

Lucia Ferrazzano, Dario Corbisiero, Giulia Martelli, Alessandra Tolomelli, Angelo Viola, Antonio Ricci, and Walter Cabri*

ACS Sustainable Chem. Eng. 2019, 7, 15, 12867-12877

The final published version is available online at:

DOI: 10.1021/acssuschemeng.9b01766

Rights / License:

The terms and conditions for the reuse of this version of the manuscript are specified in the publishing policy. For all terms of use and more information see the publisher's website: https://acsopenscience.org/open-access/publishing-options/

This item was downloaded from IRIS Università di Bologna (https://cris.unibo.it/)

When citing, please refer to the published version. 


\title{
Green Solvent Mixtures for Solid-Phase Peptide Synthesis: A Dimethylformamide-Free Highly Efficient Synthesis of Pharmaceutical-Grade Peptides
}

\author{
Lucia Ferrazzano, ${ }^{*}+$ (i) Dario Corbisiero, ${ }^{\dagger}$ Giulia Martelli, ${ }^{\dagger}$ Alessandra Tolomelli, ${ }^{\dagger}$ Angelo Viola, ${ }^{*}$ \\ Antonio Ricci, ${ }^{*}$ and Walter Cabri*, \\ †Department of Chemistry “G. Ciamician”, Alma Mater Studiorum-University of Bologna, Via F. Selmi 2, 40126 Bologna, Italy \\ ${ }^{\ddagger}$ Fresenius Kabi iPSUM, Via San Leonardo 23, 45010 Villadose, Italy
}

\section{Supporting Information}

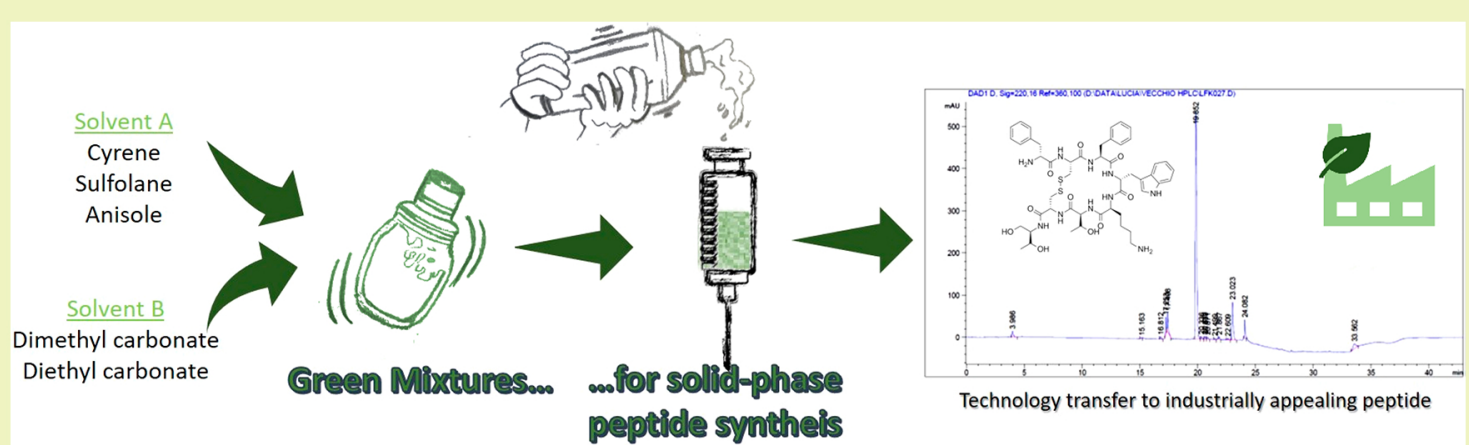

ABSTRACT: To replace dimethylformamide (DMF) in fluorenylmethoxycarbonyl (Fmoc) solid-phase peptide synthesis, we explored the application of mixtures of green solvents (green solvents mixtures for solid-phase peptide synthesis (GM-SPPS)) as combinations of Cyrene (dihydrolevoglucosenone), sulfolane, or anisole with dimethyl carbonate or diethyl carbonate, in different proportions. Their ability to swell differently functionalized polystyrene and polyethylene glycol resins was explored, and solubility of amino acids and coupling reagents was studied. Moreover, the synthesis of the model peptide Aib-enkephalin was performed in the new green mixtures, confirming the possibility to fully replace DMF all over SPPS. The two established best green protocols were then successfully applied to the synthesis of a longer peptide (Aib-ACP). Finally, the green solventbased procedure was applied to the synthesis of the reduced form of the active pharmaceutical ingredient (API) Octreotide. After oxidative cyclization and a single high-pressure column chromatography, the pharmaceutical-grade compound was isolated in comparable high yield to that obtained with the standard procedures.

KEYWORDS: Green solvents, Solvent mixtures, Solid-phase peptide synthesis, Octreotide

\section{INTRODUCTION}

The large use of solvents for synthetic chemicals manufacturing in the pharmaceutical industry represents the main contribution to the total mass of the entire process. Efficient extractions and purifications mainly contribute to acceptable product purity, necessary to be in agreement with the regulatory requirements of an active pharmaceutical ingredient (API). ${ }^{1-3}$ For this reason the solvents represent $80-90 \%$ of the total waste mass of a synthetic process. In addition, even considering the solvent only as the reaction medium, its key role in the toxicity of the overall process should be carefully taken into consideration. ${ }^{4,5}$ Due to the increasing demand from the chemical and pharmaceutical markets for synthetic peptides in the last 30 years, the attention to the greening of their production represents a relevant challenge. ${ }^{6}$ If the synthesis of small peptides could be performed in solution by using orthogonal protected amino acids, for the preparation of longer peptides the high number of synthetic and purification steps make this approach unfavored. In this context, the solid-phase peptide synthesis (SPPS) introduced by Merrifield ${ }^{7}$ in 1963 and the development by Carpino and Han of Fmoc orthogonal protecting strategy ${ }^{8}$ allowed faster synthetic processes for a larger number of peptides. ${ }^{6,9}$ The SPPS approach requires a C-terminal amino acid to be anchored to the solid support and an $\mathrm{N}$-protecting group to be subsequently removed, in order to allow the repetition of synthetic steps until completion of the peptide. The excess of reagents and byproducts generated during the synthesis can be easily removed by filtration and washings of the functionalized solid support. This means that a large amount of solvent is required to complete the synthetic pathway. N,N-Dimethylformamide (DMF) is the most employed solvent for SPPS,

Received: March 29, 2019

Revised: $\quad$ May 13, 2019

Published: June 20, 2019 
although it is a highly reprotoxic solvent, classified as a substance of very high concern (SVHC). ${ }^{10,11}$ Because the synthetic procedures do not admit a reduction in the amount of solvent, several attempts have been reported in recent years for replacing DMF with greener solvents, according to wellknown solvent-selection guides. ${ }^{12-18}$ The first examples of green solid-phase peptide synthesis (GSPPS) were widely reported by MacMillan et al. ${ }^{18}$ and by Albericio and coworkers during the last 10 years with several papers concerning the use of less hazardous solvents such as water, ${ }^{19}$ tetrahydrofuran $^{20}$ (THF), acetonitrile ${ }^{20}$ (ACN), 2-methyltetrahydrofuran $^{21,22}$ (2-MeTHF), cyclopentyl methyl ether ${ }^{22}$ (CPME), ethyl acetate ${ }^{23}$ (EtOAc), and $\gamma$-valerolactone ${ }^{23,24}$ (GVL). Very recently, the use of $N$-butylpyrrolidone (NBP) was reported by Lopez et al. for the synthesis of a late intermediate for the preparation of Octreotide. ${ }^{25}$ In SPPS the solvent has to efficiently promote the swelling of the resins, the coupling, the deprotection, and the washing steps. A single solvent able to simultaneously afford optimal results during all these different steps may be difficult to find, and for this reason a great number of green solvents has been excluded from the reported studies. To expand the array of suitable solvents for SPPS, using mixtures of two different solvents could be a valid alternative and hence represent a novel successful tool. ${ }^{26,27}$ In fact, the chemical/physical features of solvent mixtures could be more appropriate than those exhibited by single components $^{5,28,29}$ and could show more efficient properties as swelling agents and solubilization media. For example, the viscosity of a single solvent can display negative effects on the reaction rates and mass transfer; therefore, the use of a cosolvent can reduce these drawbacks together with a reduction in the hydrogen-bonding tendency. ${ }^{1}$ In this context, we report a study focused on the replacement of DMF in SPPS with mixtures of two green solvents (GM-SPPS), obtained by mixing Cyrene (dihydrolevoglucosenone), sulfolane, or anisole with dimethyl or diethyl carbonate. The efficiency of these mixtures was first explored in the synthesis of a model peptide (Aib-Enkephalin) and evaluated in terms of resin swelling, couplings, deprotections, and washing processes. The best protocols have been selected and adopted for the synthesis of the more challenging sequence Aib-ACP (modified version of $\left.\mathrm{ACP}_{64-74}\right){ }^{30}$ This peptide is usually reported to test the goodness of the synthetic method due to the high tendency of longer peptides to aggregate during their assembly on solid support. Furthermore, the introduction of Aib residues in position 66 and 67 of the original peptide enhances the possibility to detect sequences lacking these residues (des-Aib) as a result of coupling steps prevented by sterically hindered amino acids. Finally, as recently stressed by Isidro-Llobet et al., ${ }^{31}$ it is important to demonstrate that new green protocols can be useful for industrial uptake. So, following this need, the green optimized procedure was applied to the high-yield synthesis of Octreotide ( $\$ 1.75 \mathrm{~B}$ market in 2018 according to IQVIA data) pharmaceutical-grade according to United States Pharmacopeia (USP).

\section{EXPERIMENTAL SECTION}

General Remarks. All chemicals were purchased from commercial suppliers and were used without further purification. The solvents used were of high-performance liquid chromatography (HPLC) reagent grade: anisole (Merck) $\geq 99 \%$; sulfolane (Merck) $\geq 99 \%$ (with water $\leq 0.20 \%$ ); Cyrene (CircaGroup) $\geq 99 \%$ (with $\gamma$-valerolactone $<0.01 \%$; sulfolane $<0.04 \%$ ); diethyl carbonate (Merck) $\geq 99 \%$; dimethyl carbonate (Merck) $\geq 99 \%$. Analytical HPLC was performed on an Agilent 1260 Infinity II system, and ChemStation software was used for data processing, coupled to an electrospray ionization mass spectrometer, using $\mathrm{H}_{2} \mathrm{O}+0.08 \%$ trifluoroacetic acid $/ \mathrm{CH}_{3} \mathrm{CN}$ as solvent at $25{ }^{\circ} \mathrm{C}$ (positive-ion mode, $m / z=100-1500$, fragmentor 30 V). A more detailed description of HPLC chromatograms can be found in the Supporting Information. For the heating, Minichiller 300-H OLÈ was used with $\mathrm{H}_{2} \mathrm{O}+0.1 \mathrm{~g}$ of $\mathrm{Na}_{2} \mathrm{CO}_{3} / \mathrm{L}$ as thermal fluid.

Determination of Resin Swelling. ${ }^{40}$ Resin (100 mg) was weighted into a $3 \mathrm{~mL}$ syringe fitted with a polypropylene fritted disc (void volume $=0.2 \mathrm{~mL}$ ) and closed with a cap at the bottom. Solvent $(2 \mathrm{~mL})$ was added, and the resin in the syringe was shaken for $30 \mathrm{~min}$ at room temperature, with further $5 \mathrm{~min}$ of equilibrium. The solvent was removed under vacuum through a needle introduced at the bottom of the syringe. The volume of the dry resin was then recorded, and the degree of swelling was calculated from the following formula: degree of swelling $(\mathrm{mL} / \mathrm{g})=10 \times($ measured volume -0.2$)$. All the measurements were performed in triplicate, and the data were reported as medium value. The standard deviation for each measurement is reported in the Supporting Information.

Solubility Test. Fifty $\mathrm{mg}$ of selected Fmoc amino acid was dissolved in the proper solvent at a concentration of $0.2 \mathrm{M}$. In some cases a selected pair of coupling reagents ( 3 equiv) was added to these solutions.

Solid-Phase Synthesis of H-Tyr-Aib-Aib-Phe-Leu-OH or HTyr-Aib-Aib-Phe-Leu- $\mathrm{NH}_{2}$. The synthesis was performed in a glass syringe, attached at the bottom to a vacuum source to remove excess of reagents and solvents. The resin (PS-Wang-OH $0.8-1.1 \mathrm{mmol} / \mathrm{g}$ or Rink Amide ChemMatrix $0.6 \mathrm{mmol} / \mathrm{g}, 100 \mathrm{mg}$ ) was washed with DMF, dichloromethane (DCM) and DMF or mixture, $\mathrm{iPrOH}$, and mixture $(2 \times 3 \mathrm{~mL}$ each). A solution of Fmoc-Leu-OH (3 equiv), $N, N^{\prime}$-diisopropylcarbodiimide (DIC) (3 equiv), and Oxyma Pure (3 equiv) in the proper mixture, preactivated for $5 \mathrm{~min}$, was charged onto the resin and stirred for $1 \mathrm{~h}$. After the peptide coupling, the resin was washed with DMF, DCM and DMF or mixture, $\mathrm{iPrOH}$, and mixture $(2 \times 3 \mathrm{~mL}$ each). Then, $20 \%$ piperidine in DMF or selected mixture was charged on the resin $(2 \times 3 \mathrm{~mL} \times 15 \mathrm{~min})$. The resin was washed and ready for the subsequent couplings, deprotections, and washings, as reported before, to obtain the pentapeptide. The peptide was cleaved from the resin with trifluoroacetic acid (TFA) $/ \mathrm{H}_{2} \mathrm{O} /$ triisopropylsilane (TIS) (95:2.5:2.5) solution for $2 \mathrm{~h}$ at room temperature. The crude was directly analyzed by HPLC-MS.

Solid-Phase Synthesis of H-D-Phe-Cys-Phe-D-Trp-Lys-ThrCys-Thr-ol (Linear Octreotide) in 70:30 Anisole/Dimethyl Carbonate (Method 8). The synthesis was performed in a glass syringe, attached at the bottom to a vacuum source to remove excess of reagents and solvents. The resin $(\mathrm{H}-\mathrm{Thr}(\mathrm{tBu})$-ol-2CT-PS 0.6 $\mathrm{mmol} / \mathrm{g}, 500 \mathrm{mg}$ ) was washed with $3 \mathrm{~mL}$ of $\mathrm{Mix} \mathrm{C} 3,3 \mathrm{~mL}$ of $\mathrm{iPrOH}$, and $3 \mathrm{~mL}$ of Mix C3. A preactivated solution of Fmoc-Cys(Trt)-OH (3 equiv), DIC (3 equiv), and Oxyma Pure (3 equiv) in Mix C3 (3.3 $\mathrm{mL}$ ) was charged onto the resin and stirred for $1 \mathrm{~h}$. After the peptide coupling, the resin was washed with $3 \mathrm{~mL}$ of Mix C3, $3 \mathrm{~mL}$ of $\mathrm{PrOH}$, and $3 \mathrm{~mL}$ of Mix C3. Fmoc removal was performed by adding $2 \times 3$ $\mathrm{mL}$ of $20 \%$ piperidine in Mix C3 on the resin, shaking it for $10 \mathrm{~min}$ each. After the deprotection, the resin was washed with $4 \times 3 \mathrm{~mL}$ of Mix C3. The resin was ready for the subsequent couplings, deprotections, and washings, as reported before, to obtain the decapeptide. The final washings were performed with Mix C3 $(4 \times 3$ $\mathrm{mL})$ and $\mathrm{iPrOH}(3 \times 2 \mathrm{~mL})$. The peptide was cleaved from the resin with TFA/TIS/1-dodecanthiol $(9 \mathrm{~mL} / 0.7 \mathrm{~mL} / 0.6 \mathrm{~mL})$ solution for 4 $\mathrm{h}$ at room temperature. The solution was recovered by filtration. Diisopropyl ether $(37 \mathrm{~mL})$ was added dropwise at $0-5{ }^{\circ} \mathrm{C}$ to the acidic solution until precipitation of peptide was achieved. The resulting mixture was stirred for $1.5 \mathrm{~h}$ at $0-5{ }^{\circ} \mathrm{C}$. The precipitate was filtered, washed with diisopropyl ether and petroleum ether, and dried under vacuum, affording an off-white solid. The crude was analyzed by HPLC-MS. For the synthesis with method 1, as a substitution for Mix C3 and iPrOH, DMF and DCM were used.

Cyclization of Linear Octreotide. Crude trifluoroacetate linear Octreotide ( $1 \mathrm{~g}$ of a raw synthetic product containing $82.3 \%$ or $88.0 \%$ 
of the target product according to HPLC) was dissolved in methanol $(5.5 \mathrm{~mL})$, adjusted with phosphate-buffered saline (PBS) to $\mathrm{pH} 7.5-$ $8.0(70 \mathrm{~mL})$, and mixed with a solution of hydrogen peroxide $(280$ $\mu \mathrm{L}$ ). The reaction mixture was stirred for $2 \mathrm{~h}$. The reaction mixture was acidified with acetic acid to $\mathrm{pH} 4$ and filtered. Methanol was evaporated and the remaining aqueous solution was fractionated on ChromaCon MCSGP system with $\mathrm{H}_{2} \mathrm{O} / \mathrm{ACN}$. The content of peptide in the lyophilized material was $98.1 \%(883 \mathrm{mg})$, and the purity of the peptide was $99.9 \%$ according to USP method.

\section{RESULTS AND DISCUSSION}

Resin Swelling with Mixtures of Solvents. At first, we selected three different types of resins according to the relative characteristics of their structure and bonding groups for studying their swelling properties in different green solvent mixtures: Merrifield, TentaGel, and ChemMatrix. The first one is a polystyrene (PS) resin in which the polymer is cross-linked with $1 \%$ of divinylbenzene (DVB), with a loading of $0.2-1.2$ $\mathrm{mmol} / \mathrm{g}$. This is the most employed resin as a consequence of its chemical stability, but it is also a highly hydrophobic support, due to the short length of the spacer used to separate the peptide sequence and the matrix. ${ }^{32}$ TentaGel (TG) is a well-established polyethylene glycol (PEG)-functionalized PS resin, prepared by grafting of PEG (50-70\%) to low crosslinked polystyrene by an ether linkage. This aspect is responsible for the mechanical and physicochemical properties of this support. Due to the presence of long and flexible PEG spacers, the reactive sites are less affected by the hydrophobicity of the PS matrix, and normally the reactions are faster than those performed on resins that are fully composed of PS units. Therefore, TG exhibits good swelling properties in most PEG-compatible solvents. ${ }^{33,34}$ Finally, ChemMatrix (CM) belongs to the family of pure cross-linked PEG resins. The main advantage of this resin relies in the vicinal position of carbon-oxygen bonds in the chains, generating three possible different helical arrangements: the first largely hydrophobic, the second of intermediate hydrophobicity, and the third hydrophilic. This amphiphilic nature of PEG makes the resin well-solvated in both polar and nonpolar solvents. Because this feature is beneficial for the accessibility of reactive sites and for diffusion, CM resins have been widely used in the synthesis of longer peptides and small proteins with the same procedures applied for polystyrene and TG resins. ${ }^{35-37}$ In our case, each of these matrixes (Merrifield, TG, and ChemMatrix) is considered with a functionalization with Wang linker ${ }^{38}$ or Rink Amide linker, ${ }^{39}$ both sensitive to TFA treatment for the cleavage of final peptide as a C-terminal acid or amide, respectively. Swelling properties of each of these six resins in the selected solvent mixtures were measured by adopting the method reported by Santini et al. ${ }^{40}$ Resin $(100 \mathrm{mg})$ was introduced in a syringe and swelled for 30 min under shaking with the selected solvent mixture, with $5 \mathrm{~min}$ of equilibrium at the end. A good solvent has to swell $\pm 30 \%$ of the volume observed for DMF: in detail, a solvent swelling the resin $>4.0$ $\mathrm{mL} / \mathrm{g}$ can be considered a good solvent, a moderate solvent affords $2.0-4.0 \mathrm{~mL} / \mathrm{g}$, while a solvent achieving $<2.0 \mathrm{~mL} / \mathrm{g}$ has to be considered poor.

It should be noted that a level of swelling that is too high $(\gg 4.0 \mathrm{~mL} / \mathrm{g})$ can in turn affect the efficiency of the synthesis because a smaller amount of peptide can be built on the same volume of SPPS reactor and a larger volume of solvent is then required for a uniform suspension of the resin. ${ }^{25,40,41} \mathrm{To}$ validate the reproducibility of the method, PS-Wang resin was first swelled in three common solvents (DMF, DCM, and $N$ -

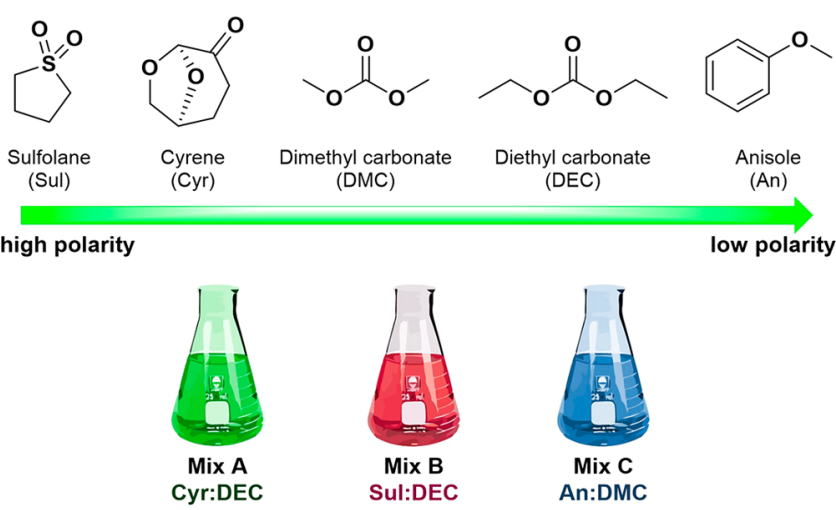

Figure 1. Green solvents chosen for the study and combinations of them in different mixtures.

methyl-2-pyrrolidone (NMP)), and the obtained results were compared with those reported in the literature ${ }^{40,41}$ (Figure S1 in the Supporting Information), confirming the efficiency of the protocol.

We then selected five green solvents (Cyrene, sulfolane, anisole, dimethyl carbonate, and diethyl carbonate) and evaluated their performance as swelling agents in mixtures (Figure 1). Despite the fact that several studies have been reported using single components, ${ }^{41}$ to the best of our knowledge mixtures of two green solvents as SPPS media have not been reported thus far. Cyrene (Cyr) is a biobased solvent produced in two steps from cellulose, ${ }^{42}$ with physical properties similar to other dipolar aprotic solvents, including NMP and DMF. ${ }^{43-45}$

Recently, it has been explored in cross-coupling reactions, ${ }^{46}$ synthesis of ureas, ${ }^{47}$ amides, ${ }^{48}$ and graphene processing. ${ }^{49}$ Sulfolane (Sul) is a dipolar aprotic industrial solvent, with water miscibility and good air stability. It is also miscible with esters, ketones, ethers, and other solvents belonging to the dipolar aprotic family. ${ }^{50}$ Anisole (An), dimethyl carbonate (DMC), and diethyl carbonate (DEC) are moderately polar aprotic solvents, reporting high scores in GSK solvent sustainability guide. ${ }^{51}$

Furthermore, carbonates, easily prepared from common alcohols, ${ }^{52,53}$ exhibit a polar behavior similar to those exhibited by DCM and THF. ${ }^{54}$ To maximize the efficiency of the selected solvents in the swelling of resins and in the solubilization of reactants, mixtures of them have been prepared as reported in Table 1. The reported two-component mixtures were then used to investigate the performance in

Table 1. Volume Ratio of the Two Components of Each Mixture $^{a}$

\begin{tabular}{ccccccccc} 
& & \multicolumn{7}{c}{ volume ratio (\%) } \\
\cline { 3 - 8 } $\operatorname{mix}$ & & 1 & 2 & 3 & 4 & 5 & 6 & 7 \\
A & Cyr & 90 & 80 & 70 & 50 & 30 & 20 & 10 \\
& DEC & 10 & 20 & 30 & 50 & 70 & 80 & 90 \\
B & Sul & 90 & 80 & 70 & 50 & 30 & 20 & 10 \\
& DEC & 10 & 20 & 30 & 50 & 70 & 80 & 90 \\
C & An & 90 & 80 & 70 & 50 & 30 & 20 & 10 \\
& DMC & 10 & 20 & 30 & 50 & 70 & 80 & 90
\end{tabular}

${ }^{a}$ Cyr = Cyrene; Sul = sulfolane; DEC = diethyl carbonate; DMC = dimethyl carbonate; $\mathrm{An}=$ anisole. All the solvents were perfectly miscible at the reported proportions. 


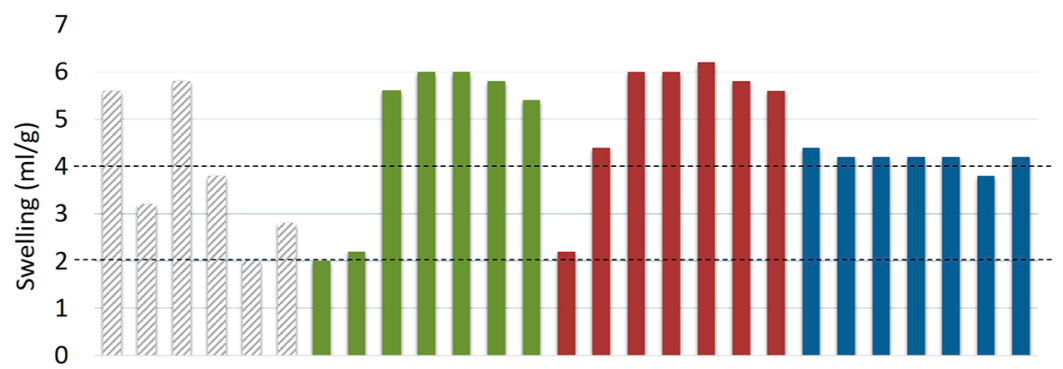

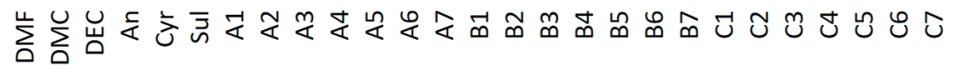

Figure 2. Swelling results of PS-Wang-OH resin.

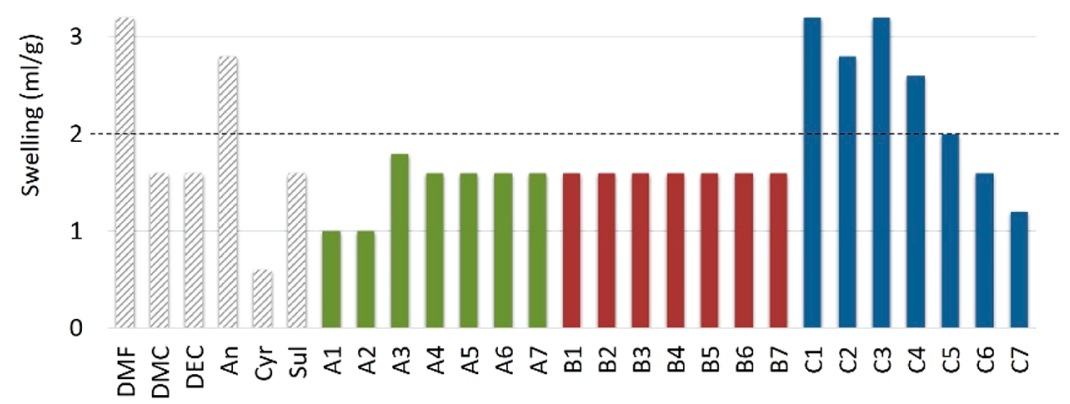

Figure 3. Swelling results of PS-RinkAmide MBHA resin.

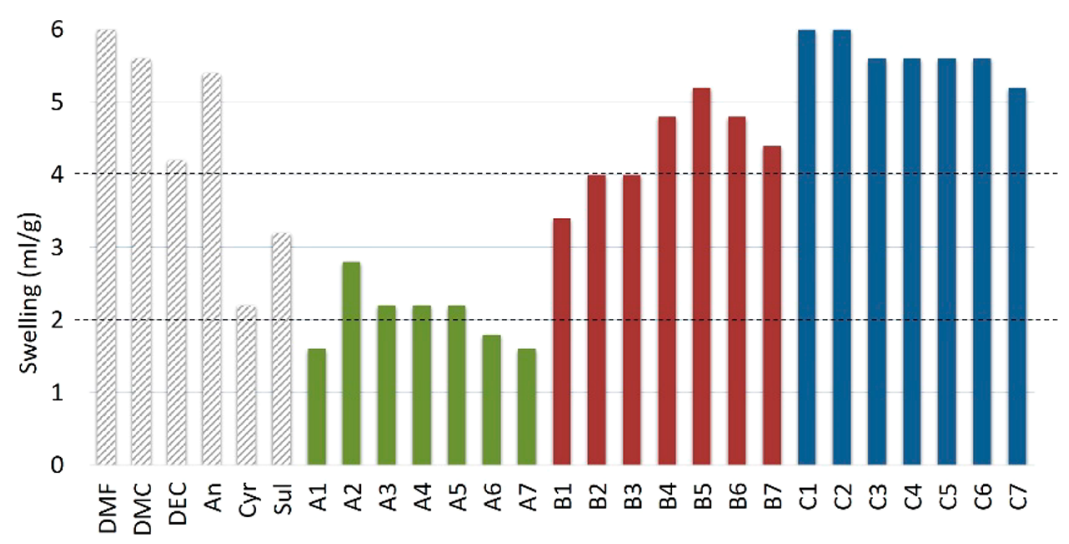

Figure 4. Swelling results of TentaGel-Wang-OH resin.

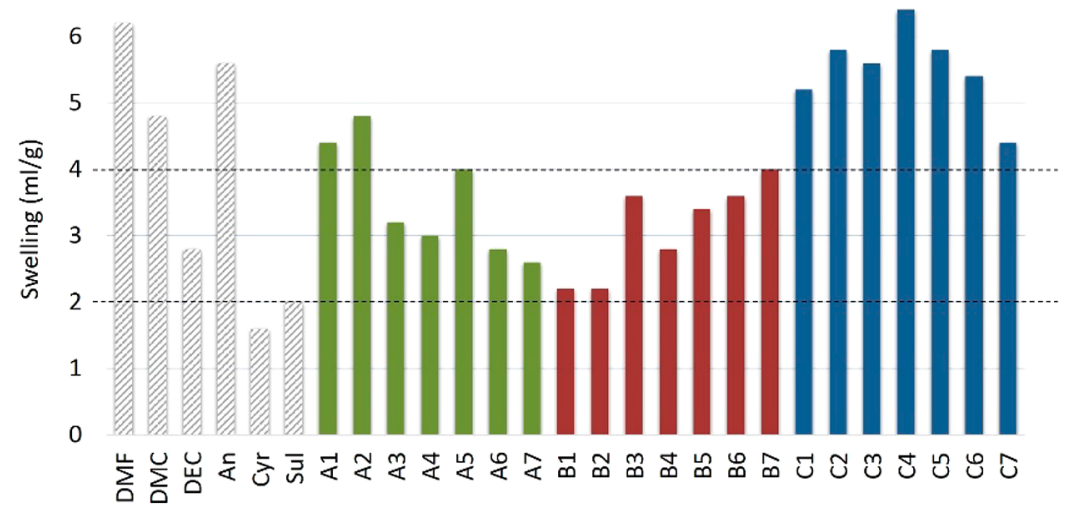

Figure 5. Swelling results of TentaGel-RinkAmide resin. 


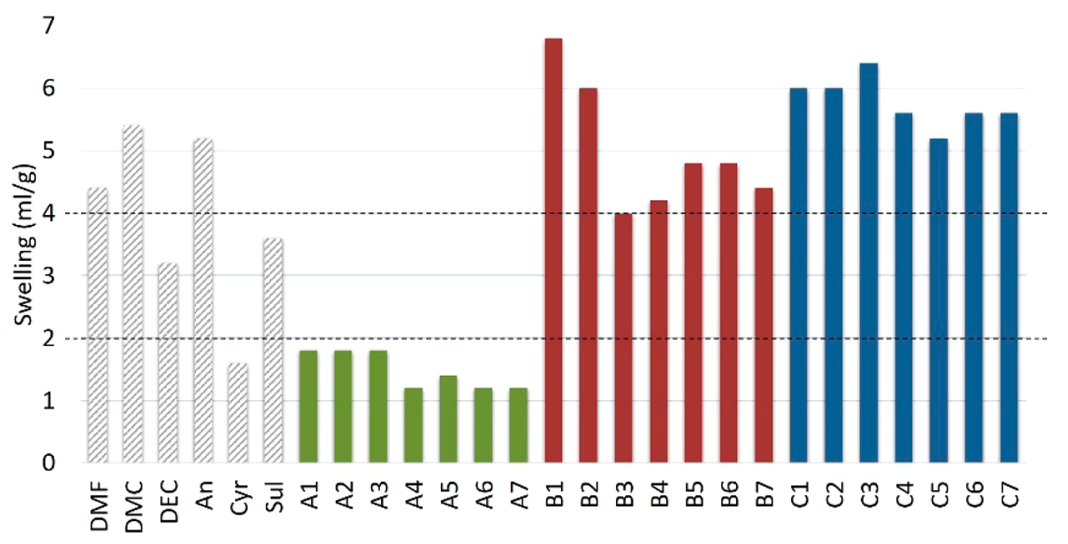

Figure 6. Swelling results of ChemMatrix-Wang-OH resin.



Figure 7. Swelling results of ChemMatrix-RinkAmide resin.

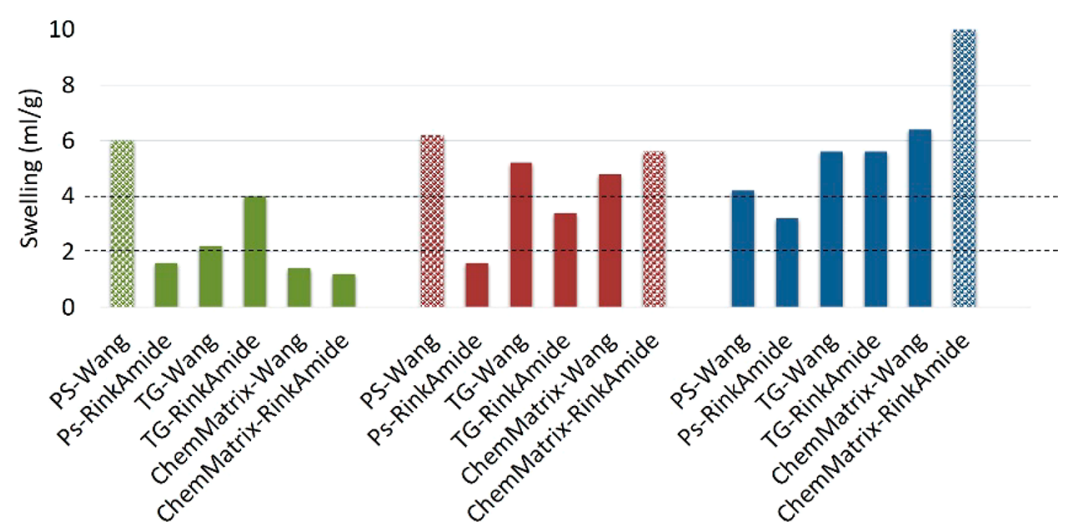

Figure 8. Comparison of resin swelling in 30:70 = Cyr/DEC alias A5 (green), 30:70 = Sul/DEC alias B5 (red), 70:30= An/DMC alias C3 (blue).

swelling for each of the six selected resins, and the results were compared to those obtained with DMF and with the single green solvents (Figures 2-7).

The collected data show a strong dependence of swelling from the solid matrix. Concerning Mixes A (green columns in Figures 2-7), the best swelling results have been obtained with PS-Wang resin and with a lower percentage of Cyrene $(\eta=$ $0.01450 \mathrm{~Pa} \cdot \mathrm{s}$ at $20{ }^{\circ} \mathrm{C}$ ), while an opposite trend has been observed for all the other resins. If PEG is present, the affinity toward Cyrene-based mixtures decreases when the PEG content in the matrix becomes higher (see ChemMatrix resins). In fact, despite the great affinity of carbonates for polyethylene glycol chains, the presence of Cyrene reduces their ability to suspend the PEG-based solid supports.

As regards Mixes B (red columns in Figures 2-7), they showed a better swelling ability when decreasing the percentage of sulfolane $\left(d=1.261 \mathrm{~g} / \mathrm{mL}\right.$ at $\left.25{ }^{\circ} \mathrm{C}\right)$, with the exception of PS-RinkAmide MBHA resin (Figure 3), which shows poor swelling in both Mixes A and B. It should be underlined that sulfolane at room temperature is close to its melting point $\left(\mathrm{mp}=20-26{ }^{\circ} \mathrm{C}, \eta=0.01007 \mathrm{~Pa} \cdot \mathrm{s}\right.$ at $\left.25^{\circ} \mathrm{C}\right)$; its mixtures with diethyl carbonate $\left(\eta=0.000749 \mathrm{~Pa} \cdot \mathrm{s}\right.$ at $\left.25^{\circ} \mathrm{C}\right)$ are much less viscous than the pure solvent and are consequently more suitable for solvation. This aspect should 
Table 2. Methods Based on Green Solvents Mixture for the Synthesis of Aib-Enkephalin Pentapeptide on PS-Wang-OH and ChemMatrix-RinkAmide

\begin{tabular}{|c|c|c|c|c|c|c|c|}
\hline & & \multicolumn{3}{|c|}{ Mix only for coupling } & \multicolumn{3}{|c|}{ Mix/iPrOH alternating } \\
\hline & $\begin{array}{c}\text { Standard } \\
\text { (method 1) } \\
{[\mathbf{a}],[\mathbf{b}]}\end{array}$ & $\begin{array}{c}\text { Mix A5 } \\
\text { (method 2) } \\
{[\mathrm{a}]}\end{array}$ & $\begin{array}{c}\text { Mix B5 } \\
\underset{[\text { (a], }[\text { b] }]}{\text { method 3) }}\end{array}$ & $\begin{array}{c}\text { Mix C3 } \\
\underset{[b]}{\text { method 4) }}\end{array}$ & $\begin{array}{c}\text { Mix A5 } \\
\underset{[a]}{\text { (method 5) }}\end{array}$ & $\begin{array}{c}\text { Mix B5 } \\
\underset{[a],[b]}{\text { method 6) }}\end{array}$ & $\begin{array}{c}\text { Mix C3 } \\
\text { (method 7) } \\
{[\text { b] }}\end{array}$ \\
\hline \multirow{3}{*}{ Swelling } & $2 \times \mathrm{DMF}$ & $2 \times \mathrm{DMF}$ & $2 \times \mathrm{DMF}$ & $2 \times \mathrm{DMF}$ & $2 \times \operatorname{MixA} 5$ & $2 \times \operatorname{Mix} B 5$ & $2 \times$ Mix C3 \\
\hline & $2 \times \mathrm{DCM}$ & $2 \times \mathrm{DCM}$ & $2 \times \mathrm{DCM}$ & $2 \times \mathrm{DCM}$ & $2 \mathrm{x} \mathrm{iPrOH}$ & $2 \times \mathrm{iPrOH}$ & $2 \times \mathrm{iPrOH}$ \\
\hline & $2 \times \mathrm{DMF}$ & $2 \times \mathrm{DMF}$ & $2 \times \mathrm{DMF}$ & $2 \times \mathrm{DMF}$ & $2 \times \operatorname{Mix}$ A5 & $2 \times \operatorname{Mix} B 5$ & $2 \times$ Mix C3 \\
\hline Deprotection & \multicolumn{4}{|c|}{$\begin{array}{c}20 \% \text { piperidine/DMF } \\
15 \mathrm{~min}\end{array}$} & $\begin{array}{c}20 \% \\
\text { pip/Mix A5 } \\
15 \mathrm{~min}\end{array}$ & $\begin{array}{c}20 \% \\
\text { pip/Mix B5 } \\
15 \mathrm{~min}\end{array}$ & $\begin{array}{c}20 \% \\
\text { pip/Mix C3 } \\
15 \mathrm{~min}\end{array}$ \\
\hline \multirow{3}{*}{ Washing } & $2 \times \mathrm{DMF}$ & $2 \times \mathrm{DMF}$ & $2 \times \mathrm{DMF}$ & $2 \times \mathrm{DMF}$ & $2 \times \operatorname{Mix}$ A5 & $2 \times \operatorname{Mix} B 5$ & 2 x Mix C3 \\
\hline & $2 \times \mathrm{DCM}$ & $2 \times \mathrm{DCM}$ & $2 \times \mathrm{DCM}$ & $2 \times \mathrm{DCM}$ & $2 \mathrm{x} \mathrm{iPrOH}$ & $2 \times \mathrm{iPrOH}$ & $2 \times \mathrm{iPrOH}$ \\
\hline & $2 \times \mathrm{DMF}$ & $2 \times \operatorname{Mix}$ A5 & $2 \times$ Mix B5 & $2 \times \operatorname{Mix} C 3$ & $2 \times \operatorname{Mix}$ A5 & $2 \times \operatorname{Mix} B 5$ & $2 \times \operatorname{Mix~C} 3$ \\
\hline
\end{tabular}

\begin{tabular}{|c|c|c|c|c|c|c|c|}
\hline \multirow{2}{*}{ Coupling } & \multicolumn{7}{|c|}{ Fmoc-AA-OH (3 eq)/DIC (3 eq)/Oxyma Pure ( 3 eq) 1 h stirring in } \\
\hline & DMF & Mix A5 & Mix B5 & Mix C3 & Mix A5 & Mix B5 & Mix C3 \\
\hline \multirow{3}{*}{ Washing } & $2 \times \mathrm{DMF}$ & $2 \times \mathrm{DMF}$ & $2 \times \mathrm{DMF}$ & $2 \times \mathrm{DMF}$ & $2 \times$ Mix A5 & $2 \times$ Mix B5 & $2 \times$ Mix C3 \\
\hline & $2 \times \mathrm{DCM}$ & $2 \times \mathrm{DCM}$ & $2 \times \mathrm{DCM}$ & $2 \times \mathrm{DCM}$ & $2 \times \mathrm{iPrOH}$ & $2 \times \mathrm{iPrOH}$ & $2 \times \mathrm{iPrOH}$ \\
\hline & $2 \times \mathrm{DMF}$ & $2 \times \mathrm{DMF}$ & $2 \times \mathrm{DMF}$ & $2 \times \mathrm{DMF}$ & $2 \times \operatorname{Mix} A 5$ & $2 \times$ Mix B5 & $2 \times$ Mix C3 \\
\hline \multirow{2}{*}{$\begin{array}{c}\text { Final } \\
\text { washing }\end{array}$} & $2 \times \mathrm{DMF}$ & $2 \times \mathrm{DMF}$ & $2 \times \mathrm{DMF}$ & $2 \times \mathrm{DMF}$ & $3 \times \operatorname{Mix}$ A5 & $3 \times$ Mix B5 & 3 x Mix C3 \\
\hline & $4 \times \mathrm{DCM}$ & $4 \times \mathrm{DCM}$ & $4 \times \mathrm{DCM}$ & $4 \times \mathrm{DCM}$ & $3 \mathrm{x}$ iPrOH & $3 \times \mathrm{iPrOH}$ & $3 \times$ iPrOH \\
\hline
\end{tabular}

${ }^{a}$ PS-Wang resin was used. ${ }^{b}$ ChemMatrix-RinkAmide resin was used.

be taken into account for the following explorations of amino acids solubility. Finally, the average trend in Mixes C (blue columns in Figure 2-7) was independent from the two solvents ratio and showed good results in all the cases, as confirmed by the low difference in viscosity of the two components (anisole: $\eta=0.000778 \mathrm{~Pa} \cdot \mathrm{s}$ at $30{ }^{\circ} \mathrm{C} ; \eta=$ $0.000585 \mathrm{~Pa} \cdot \mathrm{s}$ at $25{ }^{\circ} \mathrm{C}$ ). Furthermore, the resin terminal functionalization with Wang or RinkAmide linker did not significantly influence the swelling results.

To proceed with the investigation, we selected for each group of solvent mixtures those exhibiting the average best swelling performance, i.e., A5 (30:70 = Cyr/DEC), B5 (30:70 $=\mathrm{Sul} / \mathrm{DEC})$, and C3 (70:30 = An/DMC). In particular, better swelling was obtained with mixtures A5 and B5 on PS-Wang$\mathrm{OH}$ resin, while for ChemMatrix-RinkAmide resin mixtures B5 and C3 were the most efficient (Figure 8, dotted columns).

Solubility Screening. As mentioned before, a good solvent for SPPS should also be able to dissolve the reagents required for the peptide-coupling steps. For this reason, we screened the solubility of selected Fmoc amino acids in the chosen mixtures A5 (30:70 = Cyr/DEC), B5 (30:70 = Sul/
DEC), and C3 (70:30 = An/DMC). Fmoc-Val-OH, selected as a model amino acid, was initially suspended in the three solvent mixtures with a fixed concentration of $0.2 \mathrm{M}$.

Under these conditions, Fmoc-Val-OH was not completely soluble in mixtures A5 and C3, while it was perfectly dissolved in mixture B5. Because activated amino esters can be better dissolved in common solvents if compared to the relative free acid forms, different coupling reagent pairs were tentatively added to the suspension of Fmoc-Val-OH in the corresponding solvent mixture. Specifically, COMU/N,N-diisopropylethylamine (DIPEA), DIC/Oxyma Pure, DIC/hydroxybenzotriazole (HOBt), 1-[bis(dimethylamino)methylene]-1H-1,2,3triazolo[4,5-b]pyridinium 3-oxid hexafluorophosphate (HATU), and 2-(1H-benzotriazol-1-yl)-1,1,3,3-tetramethyluronium hexafluorophosphate (HBTU) were tested for this purpose. From these experiments, DIC/Oxyma Pure resulted in the most efficient coupling system that was able to dissolve in 5 min the Fmoc amino acid with only a pale opalescence, originated by a partial precipitation of the urea, coproduct of the amino acid activation. Moreover, the advantages of using the Oxyma Pure/DIC coupling system have been recently 
Table 3. HPLC Purities for Aib-Enkephalin Pentapeptide Assembled on PS-Wang-OH or ChemMatrix-RinkAmide under Different Conditions

\begin{tabular}{|c|c|c|c|c|c|c|c|}
\hline Entry & Method & Solvent & Resin & $\begin{array}{l}\text { Pentapeptide } \\
(\%)\end{array}$ & $\begin{array}{l}\text { des-Aib } \\
\text { (\%) }\end{array}$ & $\begin{array}{l}\text { des-Aib } 2 \\
(\%)\end{array}$ & $\begin{array}{l}\text { Other } \\
(\%)\end{array}$ \\
\hline 1 & 1 & DMF & PS-Wang & 13.5 & 11.5 & - & 75.0 \\
\hline 2 & 1 & DMF & $\mathrm{RA}-\mathrm{CM}^{[\mathrm{a}]}$ & 53.0 & 47.0 & - & - \\
\hline 3 & 2 & $\operatorname{Mix} A 5^{[c]}$ & PS-Wang & 43.6 & 29.7 & 12.9 & 13.8 \\
\hline 4 & 3 & $\operatorname{Mix} B 3^{[c]}$ & PS-Wang & 42.5 & 2.5 & - & 54.9 \\
\hline 5 & 3 & $\operatorname{Mix} B 3^{[c]}$ & RA-CM & 59.8 & 40.2 & - & - \\
\hline 6 & 4 & $\operatorname{Mix} C 3^{[c]}$ & RA-CM & 60.6 & 39.4 & - & - \\
\hline 7 & 5 & Mix A5 & PS-Wang & 37.3 & 15.6 & 8.1 & 39.0 \\
\hline 8 & 6 & Mix B3 & PS-Wang & 72.8 & 5.0 & - & 22.2 \\
\hline 9 & 6 & Mix B3 & RA-CM & 62.0 & 38.0 & - & - \\
\hline 10 & 7 & Mix C3 & RA-CM & 72.1 & 27.9 & - & - \\
\hline 11 & 5 & Mix A5 & PS-Wang ${ }^{[b]}$ & 72.0 & 12.9 & 4.2 & 10.9 \\
\hline 12 & 6 & Mix B3 & PS-Wang ${ }^{[b]}$ & 69.1 & 3.1 & - & 27.8 \\
\hline
\end{tabular}

${ }^{a}$ Refs 20 and $22 .{ }^{b}$ Loading of Leu performed twice ( $1 \mathrm{~h}$ of coupling each). ${ }^{c}$ The green mixture was used only for couplings (see Table 2 ).

demonstrated mainly for its significant reduction of racemization and efficiency in couplings higher than HOBt and 1hydroxy-7-azabenzotriazole (HOAt). ${ }^{55-62}$ Thus, the described protocol for solubility study was then applied to other amino acids with aliphatic side chains such as Fmoc-Gly-OH, FmocAla-OH, Fmoc-Leu-OH, Fmoc-Ile-OH, and Fmoc-Aib-OH; aromatic side chains such as Fmoc-Phe-OH, Fmoc-D-Phe-OH, Fmoc- $\mathrm{Tyr}(\mathrm{tBu})-\mathrm{OH}$, and Fmoc-D-Trp $(\mathrm{tBu})-\mathrm{OH}$; functionalizable side chains such as Fmoc-Lys(Boc)-OH, Fmoc-Glu(tBu)$\mathrm{OH}$, Fmoc-Arg(Boc)-OH, Fmoc-Cys(Trt)-OH, Fmoc-Asn$(\mathrm{tBu})-\mathrm{OH}$, Fmoc-Gln(Trt)-OH, and Fmoc-Asp(tBu)-OH; cyclic amino acids such as Fmoc-Pro- $\mathrm{OH}$; and branched side chain amino acids such as Fmoc-Thr(tBu)-OH. In all cases, DIC/Oxyma Pure was confirmed to be the best coupling agent system for the generation of the active species that were soluble in the reported mixtures (see Figures S2-S7 in the Supporting Information) and for this reason was employed for further explorations.

Protocol for Peptide Synthesis. The selected solvent mixtures A5, B5, and C3 were then explored in SPPS for the synthesis of Aib-enkephalin pentapeptide (H-Tyr-Aib-Aib-PheLeu-COOH/COONH${ }_{2}$ ) (Figures S8 and S9 in the Supporting Information). This peptide is a good model for a case study because the misincorporation of Aib residues could easily occur during the synthesis. The amount of the des-Aib sequences could then provide a measure of the new solvent goodness compared to DMF. The Aib-enkephalin peptide was manually assembled on two different types of resins: PS-Wang$\mathrm{OH}$ (loading 0.8-1.1 mmol/g) with Mixes A5 and B5 and ChemMatrix-RinkAmide (loading $0.6 \mathrm{mmol} / \mathrm{g}$ ) with Mixes B5 and $\mathbf{C} 3$. The first resin will furnish the corresponding $\mathrm{NH}_{2} /$ $\mathrm{COOH}$ peptide, while ChemMatrix-RinkAmide will give the corresponding $\mathrm{NH}_{2} / \mathrm{CONH}_{2}$ peptide after cleavage with TFA. In both cases the peptide was assembled on $0.1 \mathrm{~g}$ of the selected resin with DIC/Oxyma Pure as coupling reagents and piperidine as Fmoc-removal agent. The synthetic procedures with selected resins (PS-Wang and ChemMatrix-RinkAmide) and solvent mixtures (A5, B5, and C3) are summarized in Table 2.

Green solvent mixtures were employed at first only for coupling steps, and then for all synthetic steps, together with isopropanol. Synthesis carried out in DMF/DCM was also reported for comparison. The results of the different applied methods are reported in Table 3, where HPLC determined ratios of the target pentapeptide together with des-Aib, des$\mathrm{Aib}_{2}$, and other impurities are reported. Interesting results were obtained by applying methods 3 and 4 on ChemMatrixRinkAmide resin (Table 3, entries 5 and 6), i.e., when Mixes B5 and C3 were used for the coupling steps, yielding 59.8\% and $60.6 \%$ of the target pentapeptide, respectively. In these cases, the achieved result was slightly better in comparison with the synthesis performed in standard solvents (DMF/ DCM) on ChemMatrix-RinkAmide resin (entry 2)

Methods 2 and 3 on PS-Wang-OH resin (Table 3, entries 3 and 4) showed, as for reference method 1 (entry 1), a byproducts family of peptides identified as des-Leu compounds, due to the expected difficulties in the loading of the first amino acid on this resin. However, a great improvement in target peptide purity was obtained using methods 2 and 3 with PS-Wang-OH resin in comparison with method 1 , where only $13.5 \%$ of Aib-enkephalin was obtained (entries 3 and 4 vs entry 1).

Considering the first screening of the new mixtures, the synthesis of Aib-enkephalin was repeated, extending the use of mixtures A5, B5, and C3 also to washings and deprotection steps, with the aim to completely avoid the use of DMF all over the procedure. With this protocol, despite the fact that mixture A5 did not provide the expected results (purity of target 37.3\%), B5 and C3 afforded a good increase in the purity of pentapeptide (Table 3, entries 8,9 , and 10, 
respectively). In particular, a purity of $72.1 \%$ for the anisole/ dimethyl carbonate mixture on ChemMatrix-Rink Amide (entry 10) can be justified by the very good swelling tendency of this resin in the selected mixture. The use of sulfolane/ diethyl carbonate on PS-Wang-OH resin (entry 8) for all the synthetic steps showed instead a considerable reduction of desLeu sequence even if the amount of des-Aib peptide did not change significantly, in comparison with entry 4 .

Finally, we repeated the synthesis with methods 5 and 6 on PS-Wang-OH (entries 11 and 12) performing the loading of Leu to the resin twice $(2 \times 1 \mathrm{~h})$. We observed considerable reduction in des-Leu peptides content for the mixture of Cyrene/diethyl carbonate (from $39.0 \%$ to $10.9 \%$, entry 7 vs entry 11), while for the sulfolane/diethyl carbonate mixture, the purity of the target peptide remained almost unchanged.

Application of New Green Protocols to the SolidPhase Synthesis of Aib-ACP. The best operative procedures resulting from the synthesis of Aib-enkephalin (methods 6 and 7 on ChemMatrix-RinkAmide, entries 9 and 10 of Table 3) were applied for obtaining the longer peptide Aib-ACP, often used as a model due to its tendency to aggregation and folding during SPPS, leading to issues along the synthesis. The chosen peptide is a modified version of $\mathrm{ACP}_{64-74}$, naturally present in the longer peptidic sequence of acyl carrier protein of Escherchia coli. The aggregation during peptide synthesis of Aib-ACP and other long peptides is confirmed by three steps usually occurring during the synthesis: incomplete couplings, difficulties during loading of sterically hindered amino acids, and incomplete Fmoc removal. ${ }^{58}$ These sensitive steps were monitored during the synthesis of Aib-ACP decapeptide on ChemMatrix-RinkAmide by applying methods 6 and 7 (see Table 2 for more more detailed method description). Results obtained from HPLC analysis are reported in Table 4.

Table 4. HPLC Purity for Aib-ACP Decapeptide Assembled on ChemMatrix-RinkAmide Using Methods 6 and 7

$\begin{array}{cclcc}\text { entry } & \text { method }^{a} & \text { solvent } & \text { decapeptide (\%) } & \text { Des-Aib (\%) } \\ 1 & 1^{b} & \text { DMF } & 37.8 & 34.0 \\ 2 & 6 & \text { Mix B3 } & 10.0 & 14.3 \\ 3 & 7 & \text { Mix C3 } & 31.0 & 27.8\end{array}$

${ }^{a}$ Same conditions reported in Table 2. ${ }^{b}$ See ref 21.

The purity of the target Aib-ACP obtained with Mix C3 (anisole/dimethyl carbonate $=70: 30$, entry 3, Table 4) was slightly lower but comparable with that reported in the literature for the synthesis in DMF (entry 1, Table 4). A negligible amount of impurities was attributed to incomplete deprotection of N-Fmoc sequences in the case of method 7. In fact, together with the target product and its des-Aib derivative, it was possible to detect the presence of other des-AA sequences derived from expected issues in the anchoring of the last four residues of the sequence. Concerning the synthesis in Mix B5 (sulfolane/diethyl carbonate mixture, entry 2, Table 4 ), the presence of shorter sequences considerably impacts the purity of the target decapeptide (see Supporting Information, Figure S25). This evidence demonstrated that a slight improvement in mixture viscosity (B5 vs C3) has to be taken into account in the synthesis of longer peptides.

Application of GM-SPPS to the Synthesis of Pharmaceutically Interesting Peptide: Octreotide. Proceeding with a funnel selection of the above-reported conditions, we tested the feasibility of the defined new protocol in the synthesis of a peptide with pharmaceutical applications, Octreotide $\left(\mathrm{H}_{2} \mathrm{~N}\right.$-D-Phe-Cys ${ }^{2}$-Phe-D-Trp-LysThr-Cys ${ }^{7}$-Thr-ol). Mix C3 (70:30 = anisole/dimethyl carbonate) was selected for performing the chosen peptide (see Figure S27 in the Supporting Information). Although this is a medium-length peptide, the difficulties in its synthesis largely depend on the presence of Cys residues, which enhances the susceptibility to racemization induced by coupling and deprotection conditions. We used for this study a $\mathrm{H}$ $\mathrm{Thr}(\mathrm{tBu})$-ol-2CT polystyrene resin. The swelling ability of the preloaded 2CT-PS resin in the above-reported green mixtures was explored: among them, Mix C3 was the best, displaying an efficiency comparable to DMF (see Figure S28 in the Supporting Information) and was therefore selected as the synthesis medium. Specifically, the standard DCM/DMF synthesis (method 1, Table 5) was performed for comparison, together with the new green protocol (method 8, Table 5). Results obtained from the two different protocols are reported in Table 6.

The introduction of green mixture proved to be extremely efficient, yielding the target linear Octreotide with good purity, as observed in the HPLC purity profile. The main difference stands in the presence of des-Cys ${ }^{7}$ peptide when the green mixture is introduced in the protocol for all steps. No significant changes were recorded by using Mix C3 only for couplings or deprotections or modifying the coupling conditions of Fmoc-Cys(Trt)-OH (i.e., double couplings, longer couplings). It is worth noticing that all the species reported in Table 6 (except des-Cys $^{7}$ peptide) are not impurities but precursors of the final API, as confirmed by performing the oxidation of the crude, where all these species were converted in the final cyclic Octreotide under selected reaction conditions ${ }^{63}$ reported in the Experimental Section (Figures S33 and S34 and analysis by USP method in Figure S35 in the Supporting Information). To further improve the purity of the target peptide, the coupling of $\mathrm{Cys}^{7}$ in Mix C3 was performed at $40{ }^{\circ} \mathrm{C}$. ${ }^{21}$ As reported in Table 6, by heating the system a significant increase in octapeptide purity was observed ( $82.3 \%$ vs $64.6 \%$ ). This is due to almost complete absence of des-Cys ${ }^{7}$ amount. Heating the reactor for each coupling and deprotection step afforded an even higher purity profile (i.e., $84.9 \%$, see Table S1 in the Supporting Information). The results are in line with those reported by Lopez et al. ${ }^{25}$ in the green synthesis of Octreotide in $N$ butylpyrrolidone, thus opening the way to the use of green protocols for the synthesis of API peptides.

\section{CONCLUSIONS}

In this work we report the use of different green binary mixtures for solid-phase peptide synthesis as a valid alternative to standard hazardous solvents such as DMF. In particular, mixtures of Cyrene/diethyl carbonate (30:70, Mix A5), sulfolane/diethyl carbonate (30:70, Mix B5), and anisole/ dimethyl carbonate (70:30, Mix C3) showed good swelling properties for PS and PEG resins independently from their terminal functionalization. Furthermore, the selected mixtures were able to dissolve a large group of amino acids, giving the best performances by adding DIC/Oxyma Pure as coupling reagents. The synthesis of the model peptide Aib-enkephalin with anisole/dimethyl carbonate (70:30, Mix C3) on ChemMatrix-RinkAmide gave satisfactory results, in terms of HPLC purity. We also extended the optimized synthetic protocol for the development of other longer peptides. Both 
Table 5. Protocols for the Synthesis of Octreotide on H-Thr $(\mathrm{tBu})-\mathrm{ol}-2 \mathrm{CT}-\mathrm{PS}$ Resin: Comparison between Not Green and Green Methods

\begin{tabular}{|c|c|c|}
\hline & $\begin{array}{l}\text { Standard } \\
(\text { method 1) }\end{array}$ & $\begin{array}{c}\text { Mix C3, iPrOH } \\
\text { (method 8) }\end{array}$ \\
\hline \multirow{3}{*}{ Swelling } & \multirow{3}{*}{$\mathrm{DMF}$} & 1 x Mix C3 \\
\hline & & 1 x Mix C3 \\
\hline & & $1 \times$ Mix C3 \\
\hline Deprotection & $\begin{array}{c}20 \% \mathrm{pip} / \mathrm{DMF} \\
10 \mathrm{~min} \\
\end{array}$ & $\begin{array}{c}20 \% \mathrm{pip} / \mathrm{DMF} \\
10 \mathrm{~min} \\
\end{array}$ \\
\hline Washings & $4 \times \mathrm{DMF}$ & 4 x Mix C3 \\
\hline \multirow[t]{2}{*}{ Coupling } & \multicolumn{2}{|c|}{ Fmoc-AA-OH ( 3 eq)/DIC ( 3 eq)/Oxyma Pure $(3$ eq $) 1 \mathrm{~h}, \mathrm{rt}$ in } \\
\hline & DMF & Mix C3 \\
\hline \multirow{3}{*}{ Washings } & \multirow{3}{*}{$3 \times \mathrm{DMF}$} & 1 x Mix C3 \\
\hline & & $1 \times \mathrm{iPrOH}$ \\
\hline & & $1 \times \operatorname{Mix} \mathrm{C} 3$ \\
\hline \multirow{2}{*}{ Final washings } & $4 \times \mathrm{DMF}$ & 4 x Mix C3 \\
\hline & $3 \times \mathrm{DCM}$ & $3 \times$ iPrOH \\
\hline
\end{tabular}

Cleavage

TFA/TIS/1-dodecanthiol (87:6:7)

Table 6. HPLC Purity of Linear Octreotide by Using Method 1, Method 8, and Method 8 at $40{ }^{\circ} \mathrm{C}$

\begin{tabular}{|c|c|c|c|}
\hline description & $\begin{array}{l}\text { standard } \\
(\text { method 1) }\end{array}$ & $\begin{array}{c}\text { Mix } \mathrm{C} 3, \mathrm{iPrOH} \\
(\text { method } 8)\end{array}$ & $\begin{array}{l}\text { method } 8+\mathrm{Cys}^{7 b} \\
\text { coupling at } 40{ }^{\circ} \mathrm{C}\end{array}$ \\
\hline $\begin{array}{l}\text { target product } \\
\text { N,O-shifted } 1\end{array}$ & 1.9 & 8.4 & 3.2 \\
\hline $\begin{array}{l}\text { target product } \\
\text { N,O-shifted } 2\end{array}$ & 3.2 & 15.7 & 4.1 \\
\hline $\operatorname{desCys}^{7 b}$ & & 9.2 & 0.9 \\
\hline target product & 66.2 & 36.9 & 62.7 \\
\hline $\begin{array}{l}\text { target product }+ \\
\mathrm{CO}_{2}\end{array}$ & 0.7 & 1.0 & 1.1 \\
\hline$\underset{\mathrm{tBu}}{\operatorname{target} \text { product }+}$ & 12.0 & 2.2 & 8.9 \\
\hline $\begin{array}{l}\text { target product }+ \\
\mathrm{tBu}_{2}\end{array}$ & 4.0 & 0.4 & 2.3 \\
\hline sum of unknown & 12.0 & 35.4 & 17.7 \\
\hline product purity $^{a}$ & 88.0 & 64.6 & 82.3 \\
\hline
\end{tabular}

${ }^{a}$ HPLC purity calculated as sum of all target product adducts. ${ }^{b}$ The apex " 7 " stands for the position in the sequence.

Aib-ACP and linear Octreotide were in fact successfully obtained using an anisole/dimethyl carbonate mixture (Mix C3). In particular, for the synthesis of Octreotide, by heating the reactor during the low-performing steps it is possible to obtain a purity profile comparable to that obtained with DMF, thus demonstrating that the novel green protocol may replace the traditional DMF-based one for industrial peptide synthesis, showing applicability on a wide range of oligopeptides. Moreover, applying the new green methodology is possible to obtain a high-purity API that is free from synthetic impurities that can limit the commercial availability.

\section{ASSOCIATED CONTENT}

\section{S Supporting Information}

The Supporting Information is available free of charge on the ACS Publications website at DOI: 10.1021/acssuschemeng.9b01766.

Validation of swelling method; pictures of amino acids solutions in Mixes B5 and C3 in the presence of DIC/ Oxyma Pure; schemes of solid-phase peptide synthesis on resins functionalized with Wang or RinkAmide linkers; chromatograms of Aib-enkephalin peptide assembled according to all the reported methods; mass spectra of Aib-enkephalin and related defined impurities; scheme of solid-phase peptide synthesis of Octreotide; swelling results in the above-reported mixtures of $\mathrm{H}$ $\mathrm{Thr}(\mathrm{tBu})$-ol-2-CTC-PS resin; chromatograms of linear Octreotide assembled according method 1, method 8, and method 8 at $40{ }^{\circ} \mathrm{C}$ for all the steps and at $40{ }^{\circ} \mathrm{C}$ for the $\mathrm{Cys}^{7}$ coupling; table of HPLC purity profile of linear Octreotide synthesized at $40{ }^{\circ} \mathrm{C}$; chromatogram of Octreotide after oxidative cyclization (PDF)

\section{AUTHOR INFORMATION}

\section{Corresponding Authors}

*E-mail: lucia.ferrazzano4@unibo.it.

*E-mail: walter.cabri@fresenius-kabi.com. 


\section{ORCID}

\section{Lucia Ferrazzano: 0000-0002-7083-2211}

\section{Funding}

This work was supported by funding from University of Bologna and Fresenius Kabi iPSUM.

\section{Notes}

The authors declare no competing financial interest.

\section{ACKNOWLEDGMENTS}

Special thanks to Circa Group for providing Cyrene used in this study.

\section{ABBREVIATIONS}

An, anisole; DMC, dimethyl carbonate; DEC, diethyl carbonate; Sul, sulfolane; Cyr, Cyrene; PS, polystyrene; PEG, polyethylene glycole; 2-CT, 2-chlorotrityl; HPLC, highpressure liquid chromatography; USP, United States Pharmacopeia

\section{REFERENCES}

(1) Clarke, C. J.; Tu, W.; Levers, O.; Bröhl, A.; Hallett, J. P. Green and Sustainable Solvents in Chemical Processes. Chem. Rev. 2018, 118 (2), 747-800

(2) Sheldon, A. R. Green solvents for sustainable organic synthesis: state of the art. Green Chem. 2005, 7, 267-278.

(3) Roschangar, F.; Colberg, J.; Dunn, P. J.; Gallou, F.; Hayler, J. D.; Koenig, S. G.; Kopach, M. E.; Leahy, D. K.; Mergelsberg, I.; Tucker, J. L.; et al. A deeper shade of green: inspiring sustainable drug manufacturing. Green Chem. 2017, 19, 281-285.

(4) Constable, D. J.; Jimenez-Gonzalez, C.; Henderson, R. K. Perspective on Solvent Use in the Pharmaceutical Industry. Org. Process Res. Dev. 2007, 11, 133-137.

(5) Reichardt, C. Solvents and Solvent Effects: An Introduction. Org. Process Res. Dev. 2007, 11 (1), 105-113.

(6) Bray, B. L. Large-scale manufacture of peptide therapeutics by chemical synthesis. Nat. Rev. Drug Discovery 2003, 2 (7), 587-593.

(7) Merrifield, R. B. Solid Phase Peptide Synthesis. I. The Synthesis of a Tetrapeptide. J. Am. Chem. Soc. 1963, 85 (14), 2149-2154.

(8) Carpino, L. A.; Han, G. Y. 9-Fluorenylmethoxycarbonyl function, a new base-sensitive amino-protecting group. J. Am. Chem. Soc. 1970, 92 (19), 5748-5749.

(9) Palomo, J. M. Solid-phase peptide synthesis: an overview focused on the preparation of biologically relevant peptides. RSC Adv. 2014, 4, 32658-32672.

(10) Dunn, P. J. The importance of Green Chemistry in Process Research and Development. Chem. Soc. Rev. 2012, 41, 1452-1461.

(11) Alfonsi, K.; Colberg, J.; Dunn, P. J.; Fevig, T.; Jennings, S.; Johnson, T. A.; Kleine, H. P.; Knight, C.; Nagy, M. A.; Perry, D. A.; Stefaniak, M. Green chemistry tools to influence a medicinal chemistry and research chemistry based organisation. Green Chem. 2008, 10, 31-36.

(12) Amelio, A.; Genduso, G.; Vreysen, S.; Luis, P.; Van der Bruggen, B. Guidelines based on life cycle assessment for solvent selection during the process design and evaluation of treatment alternatives. Green Chem. 2014, 16, 3045-3063.

(13) Prat, D.; Hayler, J.; Wells, A. A survey of solvent selection guides. Green Chem. 2014, 16, 4546-4551.

(14) Benazzouz, A.; Moity, L.; Pierlot, C.; Sergent, M.; Molinier, V.; Aubry, J. M. Selection of a Greener Set of Solvents Evenly Spread in the Hansen Space by Space-Filling Design. Ind. Eng. Chem. Res. 2013, 52, 16585-16597.

(15) Prat, D.; Pardigon, O.; Flemming, H. W.; Letestu, S.; Ducandas, V.; Isnard, P.; Guntrum, E.; Senac, T.; Ruisseau, S.; Cruciani, P.; Hosek, P. Sanofi's Solvent Selection Guide: A Step Toward More Sustainable Processes. Org. Process Res. Dev. 2013, 17 (12), 15171525.
(16) Bergkamp, L.; Herbatschek, N. Regulating Chemical Substances under REACH: The Choice Between Authorization and Restriction and the Case of Dipolar Aprotic Solvents. RECIEL 2014, 23 (2), 221-245.

(17) Byrne, F. P.; Jin, S.; Paggiola, G.; Petchey, T. H. M.; Clark, J. H.; Farmer, T. J.; Hunt, A. J.; McElroy, C. R.; Sherwood, J. Tools and Techniques for Solvent Selection: Green Solvent Selection Guides. Sustain. Chem. Process. 2016, 4, 7-30.

(18) MacMillan, D. S.; Murray, J.; Sneddon, H. F.; Jamieson, C.; Watson, A. J. B. Evaluation of alternative solvents in common amide coupling reactions: replacement of dichloromethane and $\mathrm{N}, \mathrm{N}$ dimethylformamide. Green Chem. 2013, 15, 596-600.

(19) Galanis, A. S.; Albericio, F.; Grøtli, M. Solid-Phase Peptide Synthesis in Water Using Microwave-Assisted Heating. Org. Lett. 2009, 11 (20), 4488-4491.

(20) Jad, Y. E.; Acosta, G. A.; Khattab, S. N.; de la Torre, B. G.; Govender, T.; Kruger, H. G.; El Faham, A.; Albericio, F. Peptide synthesis beyond DMF: THF and ACN as excellent and friendlier alternatives. Org. Biomol. Chem. 2015, 13, 2393-2398.

(21) Jad, Y. E.; Acosta, G. A.; Govender, T.; Kruger, H. G.; El Faham, A.; de la Torre, B. G.; Albericio, F. Green Solid-Phase Peptide Synthesis 2. 2-Methyltetrahydrofuran and Ethyl Acetate for SolidPhase Peptide Synthesis under Green Conditions. ACS Sustainable Chem. Eng. 2016, 4 (12), 6809-6814.

(22) Jad, Y. E.; Acosta, G. A.; Khattab, S. N.; de la Torre, B. G.; Govender, T.; Kruger, H. G.; El Faham, A.; Albericio, F. 2Methyltetrahydrofuran and cyclopentyl methyl ether for green solidphase peptide synthesis. Amino Acids 2016, 48 (2), 419-426.

(23) Kumar, A.; Jad, Y. E.; El-Faham, A.; de la Torre, B. G.; Albericio, F. Green solid-phase peptide synthesis 4. c-Valerolactone and $\mathrm{N}$-formylmorpholine as green solvents for solid phase peptide synthesis. Tetrahedron Lett. 2017, 58 (30), 2986-2988.

(24) Kumar, A.; Jad, Y. E.; Collins, J. M.; Albericio, F.; de la Torre, B. G. Microwave-Assisted Green Solid-Phase Peptide Synthesis Using $\gamma$-Valerolactone (GVL) as Solvent. ACS Sustainable Chem. Eng. 2018, 6, 8034-8039.

(25) Lopez, J.; Pletscher, S.; Aemissegger, A.; Bucher, C.; Gallou, F. N-Butylpyrrolidinone as Alternative Solvent for Solid-Phase Peptide Synthesis. Org. Process Res. Dev. 2018, 22 (4), 494-503.

(26) Santini, R.; Griffith, M. C.; Qi, M. A measure of solvent effects on swelling of resins for solid phase organic synthesis. Tetrahedron Lett. 1998, 39 (49), 8951-8954.

(27) Ran, Y.; Byrne, F.; Ingram, I. D. V.; North, M. Resin Swelling in Mixed Solvents Analysed using Hansen Solubility Parameter Space. Chem. - Eur. J. 2019, 25 (19), 4951-4964.

(28) Marcus, Y. Solvent mixtures-Properties and selective solvation; Marcel Dekker: New York/Besel, 2002; DOI: 10.1021/ja025309s.

(29) Reichardt, C. Solvent and solvent effects in organic chemistry, 3rd update and enlarged ed.; Wiley-VCH: Weinheim, Germany, 2003; DOI: $10.1002 / 3527601791$.

(30) Acosta, G. A.; del Fresno, M.; Paradis-Bas, M.; Rigau-DeLlobet, M.; Cote, S.; Royo, M.; Albericio, F. Solid-phase peptide synthesis using acetonitrile as a solvent in combination with PEG-based resins. J. Pept. Sci. 2009, 15 (10), 629-633.

(31) Isidro-Llobet, A.; Kenworthy, M. N.; Mukherjee, S.; Kopach, M. E.; Wegner, K.; Gallou, F.; Smith, A. G.; Roschangar, F. Sustainability Challenges in Peptide Sythesis and Purification: from R\&D to Production. J. Org. Chem. 2019, 84 (8), 4615-4628.

(32) Li, W.; Yan, B. Effects of Polymer Supports on the Kinetics of Solid-Phase Organic Reactions: A Comparison of Polystyrene- and TentaGel-Based Resins. J. Org. Chem. 1998, 63 (12), 4092-4097.

(33) Bayer, E.; Dengler, M.; Hemmasi, B. Peptide synthesis on the new polyoxyethylene-polystyrene graft copolymer, synthesis of insulin B 21-30. Int. J. Pept. Protein Res. 1985, 25 (2), 178-186.

(34) Bayer, E. Towards the Chemical Synthesis of Proteins. Angew. Chem., Int. Ed. Engl. 1991, 30 (2), 113-129.

(35) Garcia-Martin, F.; Quintanar-Audelo, M.; Garcia-Ramos, Y.; Cruz, L. J.; Gravel, C.; Furic, R.; Coté, S.; Tulla-Puche, J.; Albericio, F. ChemMatrix, a Poly(ethylene glycol)-Based Support for the Solid- 
Phase Synthesis of Complex Peptides. J. Comb. Chem. 2006, 8 (2), 213-220.

(36) Meldal, M. Methods in enzymology, solid-phase peptide synthesis; Fields, G. B., Ed.; Academic Press: Orlando, FL, 1997; Vol. 289, pp 3-780.

(37) Garcia-Ramos, Y.; Paradis-Bas, M.; Tulla-Puche, J.; Albericio, F. ChemMatrix ${ }^{\circledR}$ for complex peptidesand combinatorial chemistry. J. Pept. Sci. 2010, 16, 675-678.

(38) Wang, S. S. ; p-Alkoxybenzyl Alcohol Resin and pAlkoxybenzyloxycarbonylhydrazide Resin for Solid Phase Synthesis of Protected Peptide Fragments. J. Am. Chem. Soc. 1973, 95 (4), $1328-1333$.

(39) Rink, H. Solid-phase synthesis of protected peptide fragments using a trialkoxy-diphenyl-methylester resin. Tetrahedron Lett. 1987, 28 (33), 3787-3790.

(40) Santini, R.; Griffith, M. C.; Qi, M. A measure of solvent effects on swelling of resins for solid phase organic synthesis. Tetrahedron Lett. 1998, 39, 8951-8954.

(41) Lawrenson, S.; North, M.; Peigneguy, F.; Routledge, A. Greener solvents for solid-phase synthesis. Green Chem. 2017, 19, 952-962.

(42) Sherwood, J.; De bruyn, M.; Constantinou, A.; Moity, L.; McElroy, C. R.; Farmer, T. J.; Duncan, T.; Raverty, W.; Hunt, A. J.; Clark, J. H. Dihydrolevoglucosenone (Cyrene) as a bio-based alternative for dipolar aprotic solvents. Chem. Commun. 2014, 50, 9650-9652.

(43) Cao, F.; Schwartz, T. J.; McClelland, D. J.; Krishna, S. H.; Dumesic, J. A.; Huber, G. W. Dehydration of cellulose to levoglucosenone using polar aprotic solvents. Energy Environ. Sci. 2015, 8, 1808-1815.

(44) Jin, S.; Byrne, F.; McElroy, C. R.; Sherwood, J.; Clark, J. H.; Hunt, A. J. Challenges in the development of biobased solvents: a case study on methyl(2,2-dimethyl-1,3-dioxolan-4-yl)methyl carbonate as an alternative aprotic solvent. Faraday Discuss. 2017, 202, 157-173.

(45) Krishna, S. H.; McClelland, D. J.; Rashke, Q. A.; Dumesic, J. A.; Huber, G. W. Hydrogenation of levoglucosenone to renewable chemicals. Green Chem. 2017, 19, 1278-1285.

(46) Wilson, K. L.; Murray, J.; Jamieson, C.; Watson, A. J. B. Cyrene as a Bio-Based Solvent for the Suzuki-Miyaura Cross-Coupling. Synlett 2018, 29, 650-654.

(47) Mistry, L.; Mapesa, K.; Bousfield, T. W.; Camp, J. E. ; Synthesis of ureas in the bio-alternative solvent Cyrene. Green Chem. 2017, 19, 2123-2128.

(48) Wilson, K. L.; Murray, J.; Jamieson, C.; Watson, A. J. B. Cyrene as a bio-based solvent for HATU mediated amide coupling. Org. Biomol. Chem. 2018, 16, 2851-2854.

(49) Salavagione, H. J.; Sherwood, J.; De bruyn, M.; Budarin, V. L.; Ellis, G. J.; Clark, J. H.; Shuttleworth, P. S. dentification of high performance solvents for the sustainable processing of graphene. Green Chem. 2017, 19, 2550-2560.

(50) Tilstam, U. Sulfolane: A Versatile Dipolar Aprotic Solvent. Org. Process Res. Dev. 2012, 16, 1273-1278.

(51) Alder, C. M.; Hayler, J. D.; Henderson, R. K.; Redman, A. M.; Shukla, L.; Shuster, L. E.; Sneddon, H. F. Updating and further expanding GSK's solvent sustainability guide. Green Chem. 2016, 18, 3879-3890.

(52) Honda, M.; Tamura, M.; Nakagawa, Y.; Sonehara, S.; Suzuki, K.; Fujimoto, K.; Tomishige, K. Ceria-Catalyzed Conversion of Carbon Dioxide into Dimethyl Carbonate with 2-Cyanopyridine. ChemSusChem 2013, 6 (8), 1341-1344.

(53) Prymak, I.; Kalevaru, V. N.; Wohlrab, S.; Martin, A. Continuous synthesis of diethyl carbonate from ethanol and $\mathrm{CO} 2$ over $\mathrm{Ce}-\mathrm{Zr}-\mathrm{O}$ catalysts. Catal. Sci. Technol. 2015, 5, 2322-2331.

(54) Schäffner, B.; Schäffner, F.; Verevkin, S. P.; Börner, A. Organic Carbonates as Solvents in Synthesis and Catalysis. Chem. Rev. 2010, 110 (8), 4554-4581.

(55) Paradis-Bas, M.; Tulla-Puche, J.; Albericio, F. The road to the synthesis of "difficult peptides. Chem. Soc. Rev. 2016, 45, 631-654.
(56) Itoh, M. Peptides. IV. Racemization Suppression by the Use of Ethyl 2-Hydroximino-2-cyanoacetate and Its Amide. Bull. Chem. Soc. Jpn. 1973, 46 (7), 2219-2221.

(57) Subiros-Funosas, R.; Prohens, R.; Barbas, R.; El-Faham, A.; Albericio, F. Oxyma: An Efficient Additive for Peptide Synthesis to Replace the Benzotriazole-Based HOBt and HOAt with a Lower Risk of Explosion. Chem. Eur. J. 2009, 15 (37), 9394-9403.

(58) Subiròs-Funosas, R.; El-Faham, A.; Albericio, F. Aspartimide formation in peptide chemistry: occurrence, prevention strategies and the role of N-hydroxylamines. Tetrahedron 2011, 67 (45), 85958606.

(59) Subiros-Funosas, R.; Khattab, S. N.; Nieto-Rodriguez, L.; ElFaham, A.; Albericio, F. Advances in Acylation Methodologies Enabled by Oxyma-Based Reagents. Aldrichimica Acta 2013, 46 (1), $21-41$.

(60) Jad, Y. E.; Khattab, S. N.; de la Torre, B. G.; Govender, T.; Kruger, H. G.; El-Faham, A.; Albericio, F. Oxyma-B, an excellent racemization suppressor for peptide synthesis. Org. Biomol. Chem. 2014, 12, 8379-8385.

(61) Sperry, J. B.; Minteer, C. J.; Tao, J.; Johnson, R.; Duzguner, R.; Hawksworth, M.; Oke, S.; Richardson, P. F.; Barnhart, R.; Bill, D. R.; Giusto, R. A.; Weaver, J. D. Thermal Stability Assessment of Peptide Coupling Reagents Commonly Used in Pharmaceutical Manufacturing. Org. Process Res. Dev. 2018, 22 (9), 1262-1275.

(62) Albericio, F.; El-Faham, A. Choosing the Right Coupling Reagent for Peptides: A Twenty-Five-Year Journey. Org. Process Res. Dev. 2018, 22 (7), 760-772.

(63) Sidorova, M. V.; Pal'keeva, M. E.; Molokoedov, A. S.; Az'muko, A. A.; Sekridova, A. V.; Ovchinnikov, M. V.; Levashov, P. A.; Afanasieva, O. I.; Berestetskaya, Yu.V.; Afanasieva, M. I.; Razova, O. A.; Bespalova, Zh.D.; Pokrovskii, S. N. Synthesis and properties of a new conformational antigen which models an extracellular region of $\beta 1$-adrenoreceptor. Russ. J. Bioorg. Chem. 2009, 35 (3), 285-295. Luo, D.; Smith, S. W.; Anderson, B. D. Kinetics and mechanism of the reaction of cysteine and hydrogen peroxide in aqueous solution. $J$. Pharm. Sci. 2005, 94 (2), 304-316. Zeida, A.; Babbush, R.; González Lebrero, M. C.; Trujillo, M.; Radi, R.; Estrin, D. A. Molecular basis of the mechanism of thiol oxidation by hydrogen peroxide in aqueous solution: challenging the SN2 paradigm. Chem. Res. Toxicol. 2012, 25 (3), 741-746. 